\title{
Subchronic Caffeine Exposure Induces Sensitization to Caffeine and Cross-Sensitization to Amphetamine Ipsilateral Turning Behavior Independent from Dopamine Release
}

\author{
Omar Cauli', Annalisa Pinna',2, Valentina Valentini' and Micaela Morelli*,1,2 \\ 'Department of Toxicology and Centre of Excellence for Neurobiology of Dependence, University of Cagliari, Cagliari, Italy; ${ }^{2}$ Institute CNR of \\ Neurogenetic and Neuropharmacology, Cagliari, Italy
}

\begin{abstract}
We have recently shown that repeated exposure to caffeine sensitizes rats to the motor activating effects of dopamine $D_{1}$ and $D_{2}$ receptor agonists. In order to study the role of dopamine in this effect, sensitization to caffeine and cross-sensitization between caffeine and amphetamine was evaluated by studying turning behavior and in vivo striatal dopamine release in unilaterally 6-hydroxydopaminelesioned rats. Administration of caffeine $(15 \mathrm{mg} / \mathrm{kg})$ for 2 weeks, on alternate days, induced a significant increase in ipsilateral turning behavior during the course of treatment, indicating that sensitization to caffeine took place in the intact striatum. Caffeine modestly increased dopamine release in the intact dorsa-lateral striatum and no significant difference between the first (+38\%) and the last $(+51 \%)$ injection was observed. Amphetamine $(2 \mathrm{mg} / \mathrm{kg})$ induced a significantly higher ipsilateral turning behavior in caffeine-sensitized rats than in vehicle-pretreated rats, however, a similar increase in dopamine release ( +900 and $+800 \%)$ was observed in the two groups. The results are the first demonstration that caffeine pre-exposure sensitizes the motor-stimulant effects of caffeine itself and of amphetamine. Sensitized ipsilateral turning after caffeine and amphetamine are not correlated to modification in striatal dopamine release, rather, postsynaptic modifications in dopamine and adenosine receptor interaction might be involved in the sensitization phenomena observed.

Neuropsychopharmacology (2003) 28, I752-1759, advance online publication, 09 July 2003; doi: I0.1038/sj.npp. 1300240
\end{abstract}

Keywords: caffeine; sensitization; amphetamine; adenosine receptor; striatum; turning behavior

\section{INTRODUCTION}

Caffeine psychomotor effects are influenced by dopamine transmission and both acute and long-term interactions between caffeine and dopamine agonists have been described. The basis for this reciprocal influence are attributed to the negative interaction between dopamine $D_{1}$ and $D_{2}$ receptors and adenosine $A_{1}$ and $A_{2 A}$ receptors that are blocked by caffeine (Ferré et al, 1997; Fredholm et al, 1999). Caffeine and theophylline acutely potentiate the motor-activating effects induced by dopamine receptor agonists (Ferré et al, 1991; Fredholm et al, 1983; Garrett and Griffiths, 1997; Kuribara, 1994; Misra et al, 1986) and reverse catalepsy induced by dopamine receptor antagonists (Hauber et al, 2001; Malec, 1997; Mandhane et al, 1997), whereas sensitization or upregulation of dopamine recep-

*Correspondence: Professor M Morelli, Department of Toxicology and Centre of Excellence for Neurobiology of Dependence, University of Cagliari, Via Ospedale 72, 09124 Cagliari, Italy, Tel: + 390706758663 , Fax: + 39070 67586/2, E-mail: morelli@unica.it

Received 09 August 2002; revised 06 May 2003; accepted 21 May 2003

Online publication: 22 May 2003 at http://www.acnp.org/citations/ Npp052202304/default.pdf tors sensitize rats to the motor-activating effect induced by caffeine or theophylline (Fenu et al, 2000; Fenu and Morelli, 1998; Ferré et al, 1994).

We and others (Cauli and Morelli, 2002; Gasior et al, 2000) have recently demonstrated that low stimulant doses of caffeine administered either parenterally in spaced administration or continuously in drinking solution, in contrast to daily administration or continuous oral intake of high doses, which induce tolerance to caffeine motor stimulant effects (Garrett and Holtzman, 1995; Holtzman and Finn, 1988), sensitize rats to the motor-stimulant effects induced by dopamine agonists.

The rotational (turning) behavior of rodents lesioned unilaterally in the nigrostriatal pathway with 6-hydroxydopamine (6-OHDA) (Ungerstedt, 1971) allows the study of motor responses induced by drugs that modulate dopamine transmission in the striatum. Turning behavior provides a model that has been widely used to evaluate in a quantitative way the sensitizing effects of drugs that act as direct or indirect agonists at the dopamine receptor level (Badiani et al, 1997; Henry et al, 1998; Pinna et al, 2001).

In unilaterally 6-OHDA-lesioned rats, caffeine and related methylxanthines have been reported to induce contralateral 
turning behavior (Fredholm et al, 1983; Fuxe and Ungerstedt, 1974; Herrera-Marschitz et al, 1988). A previous study of our group, however, showed that caffeine elicited contralateral turning behavior only in rats repeatedly primed with a dopamine receptor agonist (Fenu and Morelli, 1998).

In order to evaluate the role of dopamine in the motor effects produced by caffeine, we administered caffeine in a subchronic protocol of spaced injections in unilaterally 6OHDA-lesioned rats not repeatedly primed with dopamine receptor agonists and studied turning behavior and striatal dopamine release by in vivo microdialysis. Moreover, in order to investigate if spaced caffeine administrations modified the effects of drugs that increase dopamine release, amphetamine-induced turning behavior and dopamine release in the nonlesioned striatum of caffeinesensitized rats was evaluated. Doses of caffeine used in this study correspond to human consumption of approximately four/five cups of coffee.

\section{EXPERIMENTAL PROCEDURE}

\section{Animals}

Male Sprague-Dawley rats (Charles River, Calco, Italy) were used in all experiments. Rats were housed in groups of five in polycarbonate cages (33 w, $56 l, 20 h, \mathrm{~cm})$ and were allowed to settle under standard conditions (lights on 08.00-20.00; temperature $23^{\circ} \mathrm{C}$ ) with free access to food and water. Behavioral tests were performed between 10.00 and 13.00 .

All experiments were conducted in accordance with the guidelines for care and use of experimental animals of the European Communities Directive (86/609/EEC; D.L., 27.01.1992, No. 116).

\section{6-OHDA Lesions}

In order to lesion the dopaminergic nigrostriatal pathway, rats (275-300 g) were anesthetized with chloral hydrate $(400 \mathrm{mg} / \mathrm{kg}$ i.p.), placed on a David Kopf stereotaxic apparatus and injected unilaterally into the left medial forebrain bundle at coordinates $\mathrm{A}=-2.2, \mathrm{~L}=+1.5$, $\mathrm{V}=-7.8$ according to the atlas of Pellegrino et al (1979). $6-\mathrm{OHDA}-\mathrm{HCl}(8 \mu \mathrm{g} / 4 \mu \mathrm{l}$ of saline containing $0.05 \%$ ascorbic acid) was delivered through a stainless cannula, at a rate of $1 \mu \mathrm{l} / \mathrm{min}$. The injection needle was kept in place for an additional $2 \mathrm{~min}$, upon completion of the injection. All rats were pretreated with desipramine $(10 \mathrm{mg} / \mathrm{kg}$ i.p. $)$ in order to prevent damage to noradrenergic neurons.

\section{Evaluation of Turning Behavior}

Rotational behavior was measured by placing rats in hemispherical bowls with sawdust on the floor and connecting them to an automated rotameter system (Carnegie Medicine, Sweden). A direction-sensitive rotation sensor detected the number of full $\left(360^{\circ}\right)$ rotations in any direction. Rats were placed in each apparatus $30 \mathrm{~min}$ before drug administration in order to acclimatize and let them extinguish any spontaneous rotational behavior.
At 10 days after 6-OHDA infusion, rats were challenged with an injection of apomorphine $(0.2 \mathrm{mg} / \mathrm{kg}$ s.c.). Rats not showing at least 100 contralateral rotations during the 1 -htesting period were eliminated from the study. Rats were divided into two experimental groups (caffeine or vehicle) on the basis of apomorphine-induced contralateral turning behavior .

Experiments consisted of two phases: induction of caffeine sensitization and expression of amphetamine cross-sensitization.

\section{Induction of Caffeine Sensitization}

At 2 days after apomorphine challenge, rats received caffeine (15 mg/kg i.p.) or vehicle (i.p.) in spaced injections, on every other day, for 2 weeks (seven total administrations). Turning behavior was measured in hemispherical bowls for $3 \mathrm{~h}$ after each injection as described above.

\section{Expression of Amphetamine Cross-Sensitization}

At 3 days after the last caffeine or vehicle administration, all rats received the challenge injection of $\mathrm{D}$-amphetamine $(0.25$ or $2 \mathrm{mg} / \mathrm{kg}$ i.p.). Turning behavior was measured for $3 \mathrm{~h}$ after drug challenge as described above.

\section{Microdialysis Studies}

Surgery and treatments. A separate group of unilateral 6OHDA-lesioned rats were anesthetized with chloral hydrate $(400 \mathrm{mg} / \mathrm{kg}$ i.p.) placed in the David Kopf stereotaxic apparatus and implanted bilaterally in the dorsolateral striatum with vertical microdialysis probes. The microdialysis membranes (AN 69 Hospal membrane; $220 \mu \mathrm{m}$ ID and $310 \mu \mathrm{m}$ OD; molecular weight cutoff $>15000 \mathrm{Da})$ were $3 \mathrm{~mm}$ long. The coordinates used for implantation of the microdialysis probe were $0.7 \mathrm{~mm}$ anterior and $3.2 \mathrm{~mm}$ lateral to the bregma and $6.5 \mathrm{~mm}$ ventral from dura madre (Paxinos and Watson, 1998). The external portion of the probe was fixed to the skull with dental cement. After surgery, rats were individually housed in hemispherical bowls that also served as the experimental environment. Microdialysis experiments were performed in the striatum 13 (effect of acute caffeine), 25 (effect of subchronic caffeine), and 28 (effect of amphetamine in caffeine- and vehicle-pretreated rats) days after unilateral infusion of 6OHDA into the medial forebrain bundle. Rats were infused with 6-OHDA on day 1, screened with apomorphine on day 11 , implanted with microdialysis probes in both striata on days $12,24,27$, and used for the microdialysis experiments on days $13,25,28$. Caffeine was injected at a dose of $15 \mathrm{mg} /$ $\mathrm{kg}$ i.p., and amphetamine was injected at a dose of 0.25 or $2 \mathrm{mg} / \mathrm{kg}$ i.p.

Microdialysis procedure. Perfusion was started $24 \mathrm{~h}$ after implantation of the microdialysis probes, in freely moving rats, as previously described (Di Chiara et al, 1993). The inlet of the microdialysis probe was connected to a microperfusion pump (CMA/100 microinjection pump, Carnegie Medicine, Sweden), while the outlet was inserted into a $200-\mu$ l test tube. Microdialysis probes were perfused continuously with Ringer's solution $\left(\mathrm{NaCl} 147 \mathrm{mM}, \mathrm{CaCl}_{2}\right.$ 
$2.2 \mathrm{mM}, \mathrm{KCl} 4.0 \mathrm{mM}, \mathrm{pH} 7.0$ ) at a constant flow rate of $2 \mu \mathrm{l} /$ min. After a 1.5-h stabilization period, 20-min samples were collected.

Dopamine assay. A total volume of $20 \mu \mathrm{l}$ of dialysate samples were injected, without purification, into a highperformance liquid chromatograph equipped with a reverse-phase column (LC-18 DB, $15 \mathrm{~cm}, 5 \mu \mathrm{m}$ particle size, Supelco) and a coulometric detector (ESA, Coulochem II, Bedford, MA, USA) in order to quantitate dopamine. The first electrode of the detector was set at $+150 \mathrm{mV}$ (oxidation) and the second was set at $-250 \mathrm{mV}$ (reduction).

The composition of the mobile phase was $50 \mathrm{mM}$ $\mathrm{NaH}_{2} \mathrm{PO}_{4}, 5 \mathrm{mM} \mathrm{Na}_{2} \mathrm{HPO}_{4}, 0.1 \mathrm{mM} \mathrm{Na}$-EDTA, $0.5 \mathrm{mM}$ $n$-octyl sodium sulfate, and $15 \%$ methanol; $\mathrm{pH}$ was adjusted to 5.50. The mobile phase was pumped with an LKB 2150 pump at a flow rate of $1.0 \mathrm{ml} / \mathrm{min}$. The sensitivity of the assay for dopamine was $2 \mathrm{fmol} / \mathrm{sample}$.

\section{Histological Control}

At the end of experiments, rats were anesthetized with chloral hydrate $(400 \mathrm{mg} / \mathrm{kg}$ i.p.) and killed by decapitation. Coronal slices $(50 \mu \mathrm{m})$ were cut using a microtome in order to verify the position of the dialysis probes. Samples obtained from rats in which the probes were not correctly positioned were discarded.

\section{Drugs}

6-OHDA hydrochloride, desipramine hydrochloride, $R-(-)$ apomorphine hydrochloride, caffeine (free base), and D-amphetamine sulfate were purchased from Sigma-RBI Co. (Milano, Italy).

Caffeine, D-amphetamine, and desipramine were injected in a volume of $0.3 \mathrm{ml}$ i.p./100 g body weight. All drugs were dissolved in saline.

\section{Statistics}

Means \pm SE of the number of ipsilateral turns were calculated. Significance was evaluated by one-way or twoway ANOVA followed by Tukey's post hoc test. In microdialisys studies, the increase of dopamine release was expressed as percentage of basal values. Basal values were the means of five consecutive samples differing no more than $10 \%$. The significance of differences between groups was evaluated by one-way or two-way ANOVA followed by Tukey's post hoc test.

\section{RESULTS}

\section{Induction of Caffeine Sensitization}

Caffeine (15 mg/kg i.p.) treatment on alternate days (seven total administrations) elicited an ipsilateral turning behavior in unilaterally 6-OHDA-lesioned rats, which significantly increased during the course of treatment (Figure 1) (one-way ANOVA, $\mathrm{F}_{6,216}=6.13, P<0.0001, N=32-37$ ). The ipsilateral turning induced by caffeine was significantly different on days 6 and $7 v$ days 1 and 2. During the course of treatment, a few contralateral turns were observed. After

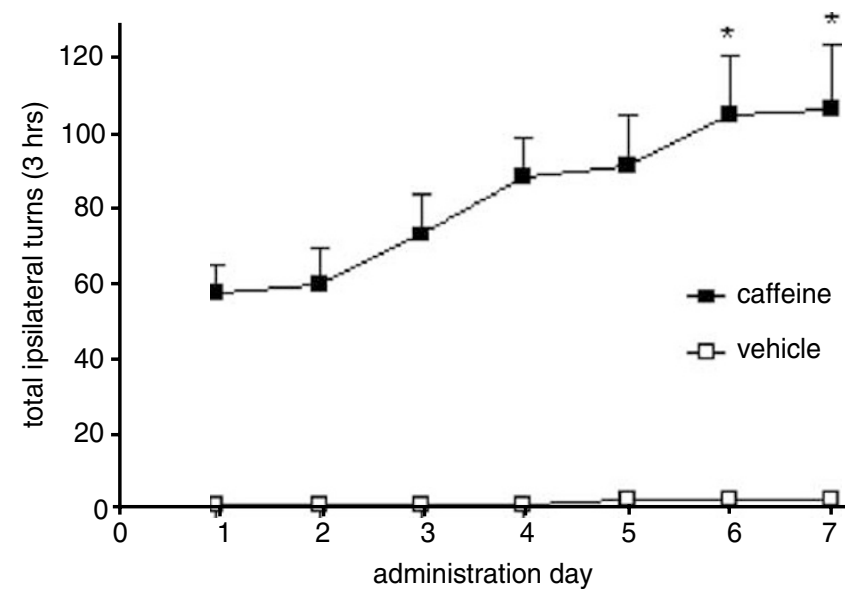

Figure I Mean \pm SEM of ipsilateral turns, recorded in 3-h-testing period, induced by caffeine ( $15 \mathrm{mg} / \mathrm{kg}$ i.p.) or vehicle (i.p.) in unilaterally 6-OHDA-lesioned rats. Caffeine or vehicle was administered for 2 weeks, on alternate days (seven total administrations). The ipsilateral turning induced by caffeine was significantly different on day 6 vs days I and 2 and on day 7 vs days I and 2 (*P $<0.001$; Tukey HSD post hoc test) $(N=32-37)$

the first caffeine administration, $1.5 \pm 0.5$ contralateral turns and after the seventh caffeine administration, $1 \pm 0.4$ contralateral turns were recorded in 3 -h testing (data not shown).

\section{Expression of Amphetamine Cross-Sensitization}

Administration of amphetamine ( $2 \mathrm{mg} / \mathrm{kg}$ i.p.) 3 days after the last caffeine or vehicle injection induced a significantly higher ipsilateral turning behavior in caffeine-pretreated as compared to vehicle-pretreated rats (Figure 2b). Two-way ANOVA analysis of the time-course of ipsilateral turning induced by amphetamine in caffeine- and vehicle-pretreated rats (Figure 2a) revealed a significant effect of group $\left(\mathrm{F}_{1,17}=5.36 ; \quad P<0.05\right), \quad$ a significant effect of time $\left(\mathrm{F}_{11,187}=15.94 ; P<0.0001\right)$, and a significant interaction $\left(\mathrm{F}_{11,187}=2.62 ; P<0.01\right)$ suggesting that sensitization in the control nonlesioned striatum took place. Administration of $0.25 \mathrm{mg} / \mathrm{kg}$ of amphetamine failed to induced turning behavior in both vehicle- and caffeine-pretreated rats (Figure 2a).

\section{Effect of Acute and Subchronic Caffeine on Dopamine Release}

Acute administration of caffeine ( $15 \mathrm{mg} / \mathrm{kg}$ i.p.) induced a significant increase of dopamine release as compared to basal dopamine release in the dorso-lateral nonlesioned striatum of unilaterally 6-OHDA-lesioned rats (Figure 3). The Tukey HSD post hoc test showed a statistically significant difference between basal and caffeine-induced dopamine release at 120 and $140 \mathrm{~min}$. Similar to acute caffeine, administration of caffeine $(15 \mathrm{mg} / \mathrm{kg}$ i.p.) to subchronically caffeine-treated rats induced a significant increase of dopamine release as compared to basal dopamine release in the dorso-lateral nonlesioned striatum (Figure 3). The Tukey HSD post hoc test showed a significant difference between basal and caffeine-induced 


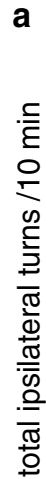
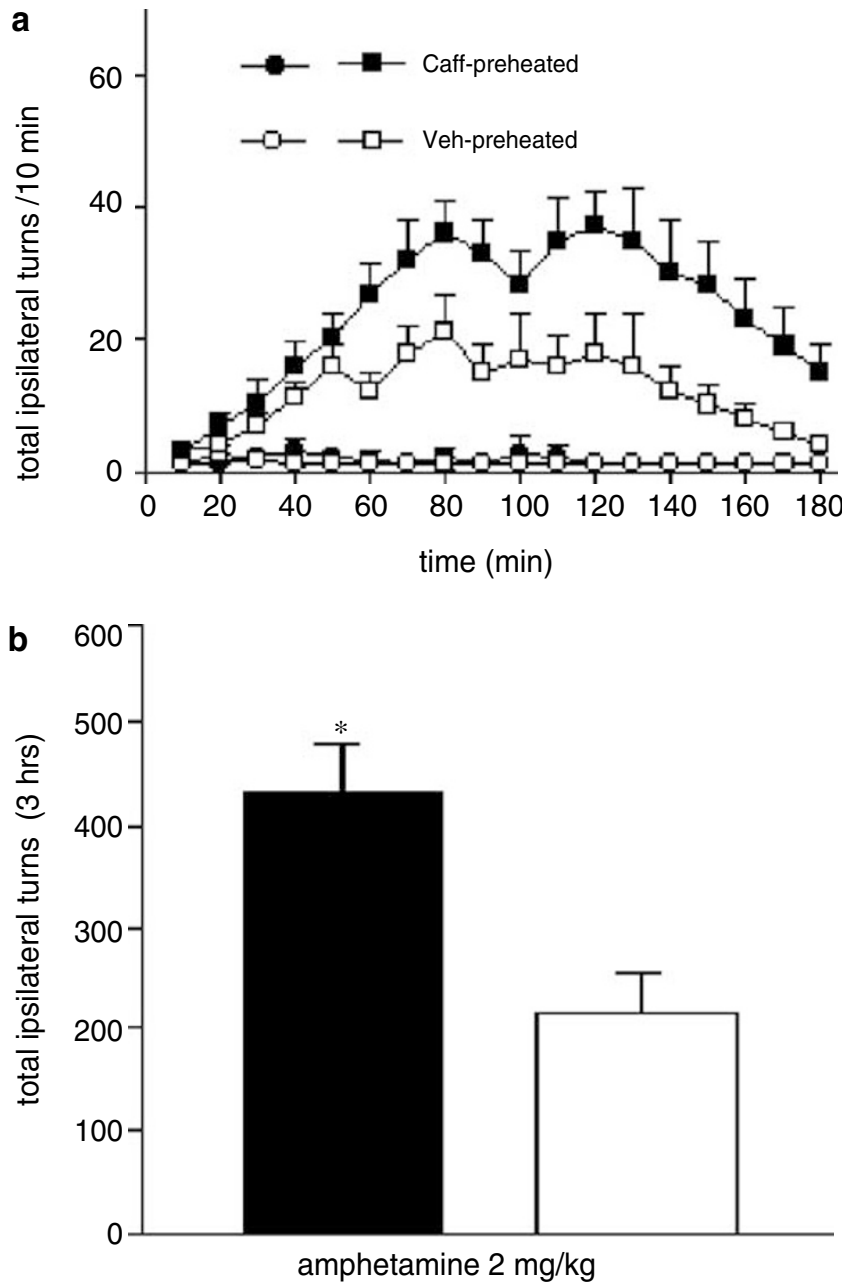

Figure 2 Mean \pm SEM of ipsilateral turns, in unilaterally 6-OHDAlesioned rats treated subchronically with caffeine ( $15 \mathrm{mg} / \mathrm{kg}$ i.p.) or vehicle (i.p.), induced by amphetamine $0.25 \mathrm{mg} / \mathrm{kg}$ i.p. (circles) and $2 \mathrm{mg} / \mathrm{kg}$ i.p. (squares), recorded every $10 \mathrm{~min}$ (a) or in total $2 \mathrm{~h}$-testing period $(2 \mathrm{mg} / \mathrm{kg}$ i.p.) (b). Significance was evaluated by two-way ANOVA followed by the Tukey HSD post hoc test $\left(F_{1,17}=4.93 ; P<0.05, N=9-10\right)$.

dopamine release at 140 and $180 \mathrm{~min}$. Two-way ANOVA analysis of the time-course of the dopamine release between the first and the seventh administration of caffeine showed no significant effect of group $\left(\mathrm{F}_{1,7}=0.42 ; P=0.54\right)$, a significant effect of time $\left(\mathrm{F}_{9,63}=5.98 ; P<0.00001\right)$, and no significant interaction $\left(\mathrm{F}_{9,63}=0.60 ; P=0.79\right)$.

Basal release of dopamine was lower than the minimum value detectable ( $<2 \mathrm{fmol}$ per sample) in the dorso-lateral striatum correspondent to the 6-OHDA-infused side.

Effect of Acute Amphetamine on Dopamine Release in Subchronically Caffeine- or Vehicle-Treated Rats

Administration of amphetamine $(2 \mathrm{mg} / \mathrm{kg}$ i.p.) to vehiclepretreated 6-OHDA-lesioned rats induced a significant increase of dopamine release as compared to basal dopamine release in the dorso-lateral nonlesioned striatum (Figure 4). In caffeine-pretreated rats, similar to vehiclepretreated rats, administration of amphetamine $(2 \mathrm{mg} / \mathrm{kg}$ i.p.) induced a significant increase of dopamine release as compared to basal dopamine release in the dorso-lateral

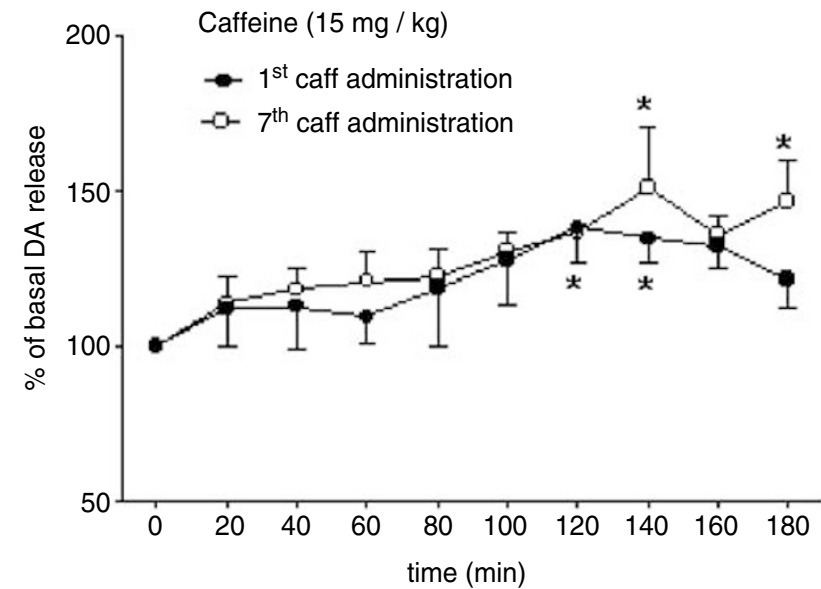

Figure 3 Effect of acute (first caffeine administration) and subchronic (seventh caffeine administration) caffeine ( $15 \mathrm{mg} / \mathrm{kg}$ i.p.) on dopamine (DA) release in the dorso-lateral nonlesioned striatum of unilaterally 6-OHDAlesioned rats. The basal output of DA was $73 \pm 13$ and $85 \pm 12 \mathrm{fmol} /$ 20 min sample, respectively $\left(F_{1,9}=0.52 ; P=0.49\right)$. Microdialysis values are mean $\pm \mathrm{SEM}$; values are expressed as percentage of basal values. Significance was evaluated by one-way ANOVA $\left(F_{927}=3.26 ; P<0.0083\right.$, $N=4$ for the first caffeine administration; $F_{9,36}=3.71 ; P<0.0023, N=5$ for the seventh caffeine administration) followed by the Tukey HSD post hoc test $(N=4-5)$. The Tukey HSD post hoc test showed a significant difference between basal and caffeine-induced dopamine release at 120 and $140 \mathrm{~min}(* P<0.05)$ and at 140 and $180 \mathrm{~min}(* P<0.05)$ for the first caffeine administration and the seventh caffeine administration, respectively. Two-way ANOVA did not reveal differences between the experimental groups.

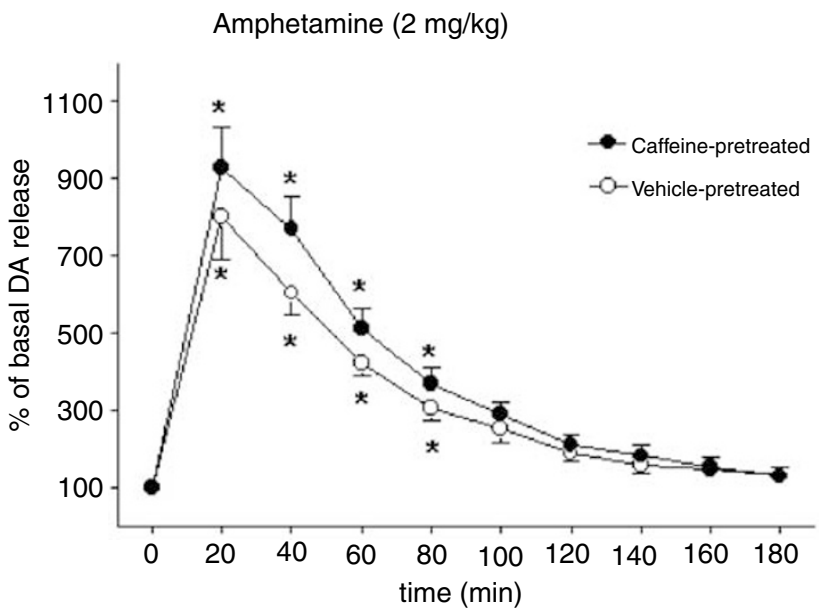

Figure 4 Effect of amphetamine $(2 \mathrm{mg} / \mathrm{kg}$ i.p.) on DA release in the dorso-lateral nonlesioned striatum of unilaterally 6-OHDA-lesioned rats treated subchronically with caffeine ( $15 \mathrm{mg} / \mathrm{kg}$ i.p.) or vehicle (i.p.). The basal output of DA was $80 \pm 9$ and $81 \pm 9 \mathrm{fmol} / 20 \mathrm{~min}$ sample, respectively. Microdialysis values are mean \pm SEM; values are expressed as percentage of basal values. Significance was evaluated by one-way ANOVA $\left(F_{9,81}=32.07 ; P<0.0000, N=10\right.$ for vehicle-pretreated rats; $F_{9,81}=45.49 ; P<0.0000, N=10$ for caffeine-pretreated rats) followed by the Tukey HSD post hoc test $(N=10)$. The Tukey HSD post hoc test showed a significant difference between basal and amphetamine-induced dopamine release at $20,40,60,80 \mathrm{~min}(* P<0.05)$ for both vehicle- and caffeine-pretreated rats. Two-way ANOVA did not reveal differences between the experimental groups.

nonlesioned striatum (Figure 4). Two-way ANOVA analysis of the time-course of the dopamine release after amphetamine administration in rats treated subchronically with vehicle or caffeine showed no significant effect of group 


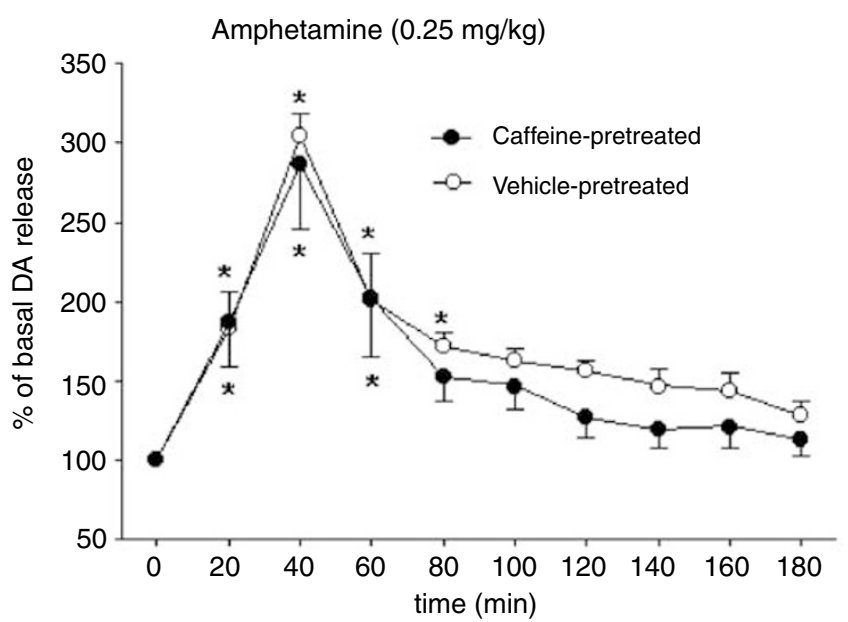

Figure 5 Effect of amphetamine $(0.25 \mathrm{mg} / \mathrm{kg}$ i.p. $)$ on DA release in the dorso-lateral nonlesioned striatum of unilaterally 6-OHDA-lesioned rats treated subchronically with caffeine $(15 \mathrm{mg} / \mathrm{kg}$ i.p.) or vehicle (i.p.). The basal output of DA was $80 \pm 9$ and $81 \pm 9 \mathrm{fmol} / 20 \mathrm{~min}$ sample, respectively. Microdialysis values are mean \pm SEM; values are expressed as percentage of basal values. Significance was evaluated by one-way ANOVA $\left(F_{9,27}=16.42 ; P<0.0000, N=4\right.$ for vehicle-pretreated rats; $F_{9.36}=10.81 ; P<0.0000, N=5$ for caffeine-pretreated rats) followed by the Tukey HSD post hoc test $(N=4-5)$. The Tukey HSD post hoc test showed a significant difference between basal and amphetamine-induced dopamine release at 20, 40,60, $80 \mathrm{~min}$ and at 20,40,60 min $(* P<0.05)$ for vehicle- and caffeine-pretreated rats, respectively. Two-way ANOVA did not reveal differences between the experimental groups.

$\left(\mathrm{F}_{1,18}=2.06 ; \quad P=0.17\right), \quad$ a significant effect of time $\left(\mathrm{F}_{9,162}=77.06 ; P<0.0000\right)$, and no significant interaction $\left(\mathrm{F}_{9,162}=0.93 ; P=0.50\right)$, showing no differences in dopamine release between the two groups.

Administration of amphetamine ( $0.25 \mathrm{mg} / \mathrm{kg}$ i.p.) induced a significant increase of dopamine release as compared to basal dopamine release in the dorso-lateral nonlesioned striatum of vehicle-pretreated rats (Figure 5). In caffeinepretreated rats, similar to vehicle-pretreated rats, administration of amphetamine $(0.25 \mathrm{mg} / \mathrm{kg}$ i.p. $)$ induced a significant increase of dopamine release as compared to basal dopamine release in the dorso-lateral nonlesioned striatum (Figure 5). Two-way ANOVA analysis of the time-course of the dopamine release after amphetamine administration in rats treated subchronically with vehicle or caffeine showed no significant effect of group $\left(\mathrm{F}_{1,7}=0.66 ; P=0.44\right)$, a significant effect of time $\left(\mathrm{F}_{9,63}=\right.$ 23.57; $P<0.0000)$, and no significant interaction $\left(\mathrm{F}_{9,63}=0.27 ; P=0.98\right)$, showing no differences in dopamine release between the two groups.

Basal release of dopamine was lower than the minimum value detectable ( $<2 \mathrm{fmol}$ per sample) in the dorso-lateral striatum corresponding to the 6-OHDA-infused side.

\section{DISCUSSION}

The present results, combining behavioral and microdialysis studies, show that: (I) subchronic caffeine administration sensitizes unilaterally 6-OHDA-lesioned rats to the ipsilateral turning behavior induced by caffeine itself; (II) rats sensitized to caffeine are cross-sensitized to amphetamine-induced ipsilateral turning behavior; (III) dopamine release induced by either caffeine or amphetamine in the intact striatum does not correlate to the sensitized turning behavior response.

\section{Turning Behavior and Dopamine Release after Subchronic Caffeine}

Adenosine $\mathrm{A}_{2 \mathrm{~A}}$ receptor blockade has been shown to mediate the motor-activating effects induced by caffeine (Chen et al, 2001; Griebel et al, 1991; Ledent et al, 1997; Svenningsson et al, 1997b) and to potentiate the effect of stimulation of postsynaptic dopamine $\mathrm{D}_{1}$ receptors (Pinna et al, 1996; Pollack and Fink, 1996) as well as dopamine $\mathrm{D}_{2}$ receptors that are colocalized with adenosine $\mathrm{A}_{2 \mathrm{~A}}$ receptors (Ferré et al, 1997; Fink et al, 1992; Schiffmann et al, 1991; Svenningsson et al, 1997a). A concurrent increase of dopamine release induced by caffeine in the intact striatum as shown by the present study might therefore synergize with postsynaptic adenosine $\mathrm{A}_{2 \mathrm{~A}}$ receptor blockade inducing ipsilateral turning behavior. Therefore, in order for caffeine to express its motor-stimulant effects, it needs either endogenous dopamine as suggested by the present study or repeated priming with dopamine receptor agonists as suggested by previous studies (Fenu and Morelli, 1998), indicating that turning behavior by caffeine is dependent on dopamine transmission.

In contrast to previous studies showing that continuous oral intake or daily high dose of caffeine administration induces tolerance to caffeine-mediated contralateral turning behavior (Casas et al, 1999; Garrett and Holtzman, 1995), the present study evidences that intermittent caffeine administration (once a day on alternate days) induces a progressive increase of ipsilateral turning behavior during the course of treatment. These results argue that sensitization, and not only tolerance, to caffeine may take place. The induction of sensitization indicates that caffeine is able to induce neuronal long-term modifications that amplify its own motor-stimulant effects.

The mechanism at the basis of this increased motor behavioral response, however, does not appear to be related to a presynaptic effect on dopamine transmission. Evaluation of dopamine release by in vivo brain microdialysis, consistent with previous studies in which caffeine was directly infused through the microdialysis probe in the striatum (Okada et al, 1997), shows that, although modestly, systemic caffeine increased dopamine release in the dorsolateral striatum. However, no significant difference on caffeine-induced dopamine release between the beginning and the end of the treatment was observed in the present study. Caffeine sensitization, therefore, does not appear to be due to an increased ability of caffeine to release dopamine. Release of dopamine by caffeine, however, might be important to trigger the induction of postsynaptic modifications at the dopamine receptor level which, together with modifications produced by repeated blockade of $\mathrm{A}_{2 \mathrm{~A}}$ receptors by caffeine, produce caffeine ipsilateral turning behavior sensitization. A recent study by Lindskog et al (2002) reported that caffeine through its effect on $A_{2 A}$ receptors increases the state of phosphorylation of DARPP32, indicating a new mechanism for the postsynaptic interaction between dopamine and adenosine $\mathrm{A}_{2 \mathrm{~A}}$ receptors that might produce long-term postsynaptic changes. 
Antagonistic interactions between dopamine $D_{1}$ and adenosine $A_{1}$ receptors have been demonstrated at both receptor and behavioral levels (Ferré et al, 1998; Gines et al, 2000; Popoli et al, 1996). These types of interactions, however, have been shown to play a pivotal role in limbic rather than in motor areas (Bonci and Williams, 1996; Kuzmin et al, 1999; Mayfield et al, 1999), whereas in turning behavior, $A_{1}$ receptor antagonists do not appear to play a central role (Pinna et al, 1996).

\section{Turning Behavior and Dopamine Release after Amphetamine in Subchronically Caffeine-Treated Rats}

Administration of amphetamine elicited a higher ipsilateralturning behavior in caffeine-sensitized rats as compared to vehicle-pretreated rats, indicating that cross-sensitization between caffeine and amphetamine takes place.

Caffeine produces active metabolites that might stimulate, although to a low degree, locomotor activity. Our experimental protocol (alternate administrations plus 3 days washout) differs from continuous oral intake or daily administration, and renders the presence of active metabolites unlikely (Lau et al, 1995; Svenningsson et al, 1999), suggesting that a mechanism of sensitization rather than a potentiation is at the basis of the amplification of turning behavior induced by amphetamine. In previous studies, in fact, the lack of washout from the last caffeine injection or caffeine solution intake could have produced a potentiation, rather than a sensitization, to the amphetamine or cocaine motor-stimulant effects (Gasior et al, 2000; Schenk et al, 1990).

As shown by previous studies, amphetamine significantly increased dopamine release in the intact striatum (Badiani et al, 2000; Di Chiara et al, 1993), however, no significant difference on dopamine release between caffeine-sensitized rats and vehicle-pretreated rats was observed in the present study. In order to exclude that the very high increase in dopamine release after $2 \mathrm{mg} / \mathrm{kg}$ of amphetamine, $+800 \%$ in vehicle, and $+900 \%$ in caffeine-pretreated rats could prevent a further increase in dopamine release, we evaluated the effect of a lower dose of amphetamine $(0.25 \mathrm{mg} / \mathrm{kg})$ that produced a maximal increase of about $300 \%$. Administration of a low dose of amphetamine that is ineffective in producing ipsilateral turning behavior, increased dopamine release to the same extent in caffeine- and vehiclepretreated rats, confirming that subchronic caffeine did not modify the dopamine-releasing effect of amphetamine. This result suggests that cross-sensitization to amphetamine, as well as caffeine sensitization, are not correlated to presynaptic changes at the level of dopamine transmission, rather, postsynaptic mechanisms which involve the interaction between adenosine and dopamine receptors in the striatum might be responsible for these effects.

Manipulation of the dopamine system, such as dopamine neuron denervation or chronic haloperidol, have been shown to lead to an increase in intramembrane interaction between adenosine $A_{2 A}$ and dopamine $D_{2}$ receptors in the striatum (Ferré and Fuxe, 1992; Ferré et al, 1994). On this basis, we hypothesize that after repeated caffeine administration, long-term modifications at the level of the $A_{2 A}$ receptor or its second messenger might lead to an increase in $A_{2 A}$ receptor sensitivity and as a consequence, in the $D_{2}$ receptor leading to the sensitized ipsilateral turning observed after caffeine and amphetamine.

Similar to this report, a previous study by Badiani et al (2000) showed that amphetamine induces sensitization to turning behavior independent from dopamine release. The failure of modifications in dopamine release in response to amphetamine in caffeine-sensitized rats is in line with previous studies showing that modifications at the postsynaptic level such as increased affinity of dopamine for $D_{1}$ receptor stimulated adenylate cyclase, increased DARPP-32 phosphorylation as well as changes in specific $G$ protein subunits, protein kinase A activity or expression of immediate-early genes are at the basis of sensitization phenomena (Barone et al, 1994; Nestler 1992; Pierce and Kalivas, 1997; Pinna et al, 1997; Striplin and Kalivas, 1993).

\section{Conclusions}

The present results show for the first time that caffeine, besides producing tolerance after continuous oral administration or repeated high dose administration, sensitizes rats to its own and amphetamine motor-stimulant effects, when administered in spaced injections. Long-term modifications of adenosine-dopamine receptor interaction at the postsynaptic level might be at the basis of the sensitization observed, since no correlation between dopamine release and sensitization to ipsilateral turning behavior was detected. Caffeine, although sharing no reinforcing properties or abuse potential with drugs of abuse, should be regarded as a drug potentially capable of priming responses induced by drugs that stimulate dopamine transmission such as amphetamine.

\section{ACKNOWLEDGEMENTS}

This study was supported by funds from Centre of Excellence for Neurobiology of Dependence (MURST).

\section{REFERENCES}

Badiani A, Camp DM, Robinson TE (1997). Enduring enhancement of amphetamine sensitization by drug-associated environmental stimuli. J Pharmacol Exp Ther 282: 787-794.

Badiani A, Oates MM, Fraioli S, Browman KE, Ostrander MM, Xue CJ et al (2000). Environmental modulation of the response to amphetamine: dissociation between changes in behavior and changes in dopamine and glutamate overflow in the rat striatal complex. Psychopharmacology 151: 166-174.

Barone P, Morelli M, Popoli M, Cicarelli G, Campanella G, Di Chiara G (1994). Behavioral sensitization in 6-hydroxydopamine lesioned rats involves the dopamine signal transduction: changes in DARPP-32 phosphorylation. Neuroscience 61: 867-873.

Bonci A, Williams JT (1996). A common mechanism mediates long-term changes in synaptic transmission after chronic cocaine and morphine. Neuron 16: 631-639.

Casas M, Prat G, Robledo P, Barbanoj M, Kulisevsky J, Jané F (1999). Repeated co-administration of caffeine and bromocriptine prevents tolerance to the effects of caffeine in the turning behavior animal model. Eur Neuropsychopharmacol 9: 515-521.

Cauli O, Morelli M (2002). Subchronic caffeine administration sensitizes rats to the motor activating effects of dopamine D1 and D2 receptor agonists. Psychopharmacology 162: 246-254. 
Chen JF, Moratalla R, Standaert D, Impagnatiello F, Grandy DK, Cuellar $\mathrm{B}$ et al (2001). The role of the $\mathrm{D}_{2}$ dopamine receptor $\left(\mathrm{D}_{2} \mathrm{R}\right)$ in $\mathrm{A}_{2 \mathrm{~A}}$ adenosine receptor $\left(\mathrm{A}_{2 \mathrm{~A}} \mathrm{R}\right)$-mediated behavioral and cellular responses as revealed by $\mathrm{A}_{2 \mathrm{~A}}$ and $\mathrm{D}_{2}$ receptor knockout mice. Proc Natl Acad Sci USA 98: 1970-1975.

Di Chiara G, Tanda G, Frau R, Carboni E (1993). On the preferential release of dopamine in the nucleus accumbens by amphetamine: further evidence obtained by vertically implanted concentric dialysis probes. Psychopharmacology 112: 398-402.

Fenu S, Cauli O, Morelli M (2000). Cross-sensitization between the motor activating effects of bromocriptine and caffeine: role of adenosine A2A receptors. Behav Brain Res 114: 97-105.

Fenu S, Morelli M (1998). Motor stimulant effects of caffeine in 6hydroxydopamine-lesioned rats are dependent on previous stimulation of dopamine receptors: a different role of $D_{1}$ and $\mathrm{D}_{2}$ receptors. Eur J Neurosci 10: 1878-1884.

Ferré S, Fredholm BB, Morelli M, Popoli P, Fuxe K (1997). Adenosine-dopamine receptor-receptor interactions as an integrative mechanism in the basal ganglia. Trends Neurosci 20: 482-486.

Ferré S, Fuxe K (1992). Dopamine denervation leads to an increase in the intramembrane interaction between adenosine $\mathrm{A} 2$ and dopamine D2 receptors in the neostriatum. Brain Res 594: 124130.

Ferré S, Herrera-Marschitz M, Grabowska-Andén M, Casas M, Ungerstedt U, Andén NE (1991). Postsynaptic dopamine/ adenosine interaction: II. Postsynaptic dopamine agonism an adenosine antagonism of methylxanthines in short-term reserpinized mice. Eur J Pharmacol 192: 31-37.

Ferré S, Schwarcz R, Li XM, Snaprud P, Ogren SO, Fuxe K (1994). Chronic haloperidol treatment leads to an increase in the intramembrane interaction between adenosine $\mathrm{A}_{2}$ and dopamine $\mathrm{D}_{2}$ receptors in the neostriatum. Psychopharmacology 116: 279284.

Ferré S, Torvinen M, Antoniou K, Irenius E, Civelli O, Arenas E et al (1998). Adenosine A1 receptor-mediated modulation of dopamine D1 receptors in stably cotransfected fibroblast cells. $J$ Biol Chem 273: 4718-4724.

Fink JS, Weaver DR, Rivkees SA, Peterfreund RA, Pollack AE, Adler EM et al (1992). Molecular cloning of the rat $A_{2}$ adenosine receptor: selective co-expression with $\mathrm{D}_{2}$ dopamine receptors in rat striatum. Mol Brain Res 14: 186-190.

Fredholm BB, Battig K, Holmen J, Nehlig A, Zvartau EE (1999). Actions of caffeine in the brain with special reference to factors that contribute to its widespread use. Pharmacol Rev 51: 83-133.

Fredholm BB, Herrera-Marschitz M, Jonzon B, Lindstrom K, Ungerstedt U (1983). On the mechanism by which methylxanthines enhance apomorphine-induced rotation behavior in the rat. Pharmacol Biochem Behav 19: 535-541.

Fuxe K, Ungerstedt U (1974). Action of caffeine and theophylline on supersensitive dopamine receptors: considerable enhancement of receptor response to treatment with DOPA and dopamine receptor agonists. Med Biol 52: 18-54.

Garrett BE, Griffiths RR (1997). The role of dopamine in the behavioral effects of caffeine in animals and humans. Pharmacol Biochem Behav 57: 533-541.

Garrett BE, Holtzman SG (1995). The effects of dopamine agonists on rotational behavior in non-tolerant and caffeine-tolerant rats. Behav Pharmacol 6: 843-851.

Gasior M, Jaszyna M, Peters J, Goldberg SR (2000). Changes in the ambulatory and discriminative stimulus effects of psychostimulant drugs in rats chronically exposed to caffeine: effect of caffeine dose. J Pharmacol Exp Ther 295: 1101-1111.

Gines S, Hillion J, Torvinen M, Le Crom S, Casado V, Canela EI et al (2000). Dopamine D1 and adenosine A1 receptors form functionally interacting heteromeric complexes. Proc Nat Acad Sci USA 97: 8606-8611.
Griebel G, Saffroy-Spittler M, Misslin R, Remmy D, Vogel E, Bourguignon JJ (1991). Comparison of the behavioural effects of an adenosine A1/A2-receptor antagonist, CGS 15943A, and an A1-selective antagonist, DPCPX. Psychopharmacology 103: 541544.

Hauber W, Neuscheler P, Nagel J, Muller CE (2001). Catalepsy induced by a blockade of dopamine D1 or D2 receptors was reversed by a concomitant blockade of adenosine A (2A) receptors in the caudate-putamen of rats. Eur J Neurosci 14: $1287-1293$.

Henry B, Crossman AR, Brotchie JM (1998). Characterisation of enhanced behavioural responses to L-DOPA following repeated administration in the 6-hydroxydopamine-lesioned rat model of Parkinson's disease. Exp Neurol 151: 334-342.

Herrera-Marschitz M, Casas M, Ungerstedt U (1988). Caffeine produces contralateral rotation in rats with unilateral dopamine denervation: comparisons with apomorphine-induced responses. Psychopharmacology 94: 38-45.

Holtzman SG, Finn IB (1988). Tolerance to behavioural effects of caffeine in rats. Pharmacol Biochem Behav 29: 411-418.

Kuribara H (1994). Modification by caffeine of the sensitization to methamphetamine and cocaine in terms of ambulation in mice. Life Sci 55: 933-940.

Kuzmin A, Johansson B, Zvartau EE, Fredholm BB (1999). Caffeine, acting on adenosine A1 receptors, prevents extinction of cocaine-seeking behavior in mice. J Pharmacol Exp Ther 290: 535-542.

Lau CE, Ma F, Falk JL (1995). Oral and IP caffeine pharmacokinetics under a chronic food-limitation condition. Pharmacol Biochem Behav 50: 245-252.

Ledent C, Vaugeois JM, Schiffmann SN, Pedrazzini T, Yacoubi ME, Vanderhaeghen JJ et al (1997). Aggressiveness, hypoalgesia and high blood pressure in mice lacking the adenosine $\mathrm{A}_{2 \mathrm{~A}}$ receptor. Nature 388: 674-678.

Lindskog M, Svenningsson P, Pozzi L, Kim Y, Flenberg AA, Bibb JA et al (2002). Involvement of DARPP-32 phosphorylation in the stimulant action of caffeine. Nature 418: 774-778.

Malec D (1997). Haloperidol-induced catalepsy is influenced by adenosine receptor antagonists. Pol J Pharmacol 49: 323-327.

Mandhane SN, Chopde CT, Ghosh AK (1997). Adenosine A2 receptors modulate haloperidol-induced catalepsy in rats. Eur J Pharmacol 328: 135-141.

Mayfield RD, Jones BA, Miller HA, Simosky JK, Larson GA, Zahniser NR (1999). Modulation of endogenous GABA release by an antagonist adenosine $A_{1}$ /dopamine $D_{1}$ receptor interaction in rat brain limbic regions but not basal ganglia. Synapse 33: 274-281.

Misra AL, Vadlamani NL, Pontani RB (1986). Effect of caffeine on cocaine locomotor stimulant activity in rats. Pharmacol Biochem Behav 24: 761-764.

Nestler EJ (1992). Molecular mechanisms of drug addiction. J Neurosci 12: 2439-2450.

Okada M, Kiryu K, Kawata Y, Mizuno K, Wada K, Tasaki H et al (1997). Determination of the effects of caffeine and carbamazepine on striatal dopamine release by in vivo microdialysis. Eur $J$ Pharmacol 321: 181-188.

Paxinos G, Watson C (1998). The Rat Brain in Stereotaxic Coordinates. Academic Press: Sydney.

Pellegrino LJ, Pellegrino AS, Cushman AJ (1979). A Stereotaxic Atlas of the Rat Brain. Plenum Press: New York.

Pierce RC, Kalivas PW (1997). A circuitry model of the expression of behavioral sensitization to amphetamine-like psychostimulants. Brain Res Brain Res Rev 25: 192-216.

Pinna A, Di Chiara G, Wardas J, Morelli M (1996). Blockade of $A_{2 A}$ adenosine receptors positively modulates turning behaviour and c-fos expression induced by $\mathrm{D}_{1}$ agonists in dopamine-denervated rats. Eur J Neurosci 8: 1176-1181. 
Pinna A, Fenu S, Morelli M (2001). Motor stimulant effects of the adenosine $\mathrm{A}_{2 \mathrm{~A}}$ receptor antagonist SCH 58261 do not develop tolerance after repeated treatments in 6-hydroxydopaminelesioned rats. Synapse 39: 233-238.

Pinna A, Morelli M, Drukarch B, Stoof JC (1997). Priming of 6hydroxydopamine-lesioned rats with L-DOPA or quinpirole results in an increase in dopamine D1 receptor-dependent cyclic AMP production in striatal tissue. Eur J Pharmacol 331: 23-26.

Pollack AE, Fink JS (1996). Synergistic interaction between an adenosine antagonist and a $\mathrm{D}_{1}$ dopamine agonist on rotational behavior and striatal c-Fos induction in 6-hydroxydopaminelesioned rats. Brain Res 743: 124-130.

Popoli P, Gimenez-Llort L, Pezzola A, Reggio R, Martinez E, Fuxe $\mathrm{K}$ et al (1996). Adenosine A1 receptor blockade selectively potentiates the motor effects induced by dopamine D1 receptor stimulation in rodents. Neurosci Lett 218: 209-213.

Schenk S, Horger B, Snow S (1990). Caffeine preexposure sensitizes rats to the motor activating effects of cocaine. Behav Pharmacol 1: $447-451$.

Schiffmann SN, Jacobs O, Vanderhaeghen JJ (1991). The striatal restricted adenosine A2 receptor (RDC8) is expressed by enkephalin but not by substance $\mathrm{P}$ neurons. An in situ hybridization histochemistry study. $J$ Neurochem 57: 1062-1067.

Striplin CD, Kalivas PW (1993). Robustness of G protein changes in cocaine sensitization shown with immunoblotting. Synapse 14: $10-15$.

Svenningsson P, Le Moine C, Kull B, Sunahara R, Bloch B, Fredholm BB (1997a). Cellular expression of adenosine $A_{2 A}$ receptor messenger RNA in the rat central nervous system with special reference to dopamine innervated areas. Neuroscience $\mathbf{8 0}$ : 1171-1185.

Svenningsson P, Nomikos GG, Fredholm BB (1999). The stimulatory action and the development of tolerance to caffeine is associated with alterations in gene expression in specific brain regions. J Neurosci 19: 4011-4022.

Svenningsson P, Nomikos GG, Ongini E, Fredholm BB (1997b). Antagonism of adenosine $A_{2 A}$ receptors underlies the behavioural activating effect of caffeine and is associated with reduced expression of messenger RNA for NGFI-A and NGFI-B in caudate-putamen and nucleus accumbens. Neuroscience 79: 753-764.

Ungerstedt U (1971). Postsynaptic supersensitivity after 6-hydroxy-dopamine induced degeneration of the nigro-striatal dopamine system. Acta Physiol Scand 367(Suppl): 69-93. 